Original Article

\title{
Role of beneficial microbes with nitrogen and phosphorous levels on canola productivity
}

\author{
Papel de microbes benéficos em associação com níveis de nitrogênio e fosforos na \\ produtividade de canola
}

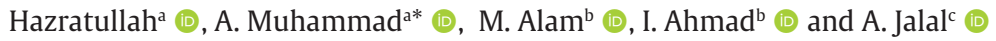 \\ aThe University of Agriculture, Department of Agronomy, Peshawar, Pakistan \\ ${ }^{b}$ The University of Agriculture, Horticulture Department, Peshawar, Pakistan \\ 'The University of Agriculture, Institute of Biotechnology \& Genetic Engineering, Peshawar, Pakistan
}

\begin{abstract}
A research was conducted to evaluate the impact of various nitrogen and phosphorus levels along with beneficial microbes to enhance canola productivity. The research was carried out at Agronomy Research Farm, The University of Agriculture Peshawar in winter 2016-2017. The experiment was conducted in randomized complete block factorial design. The study was comprised of three factors including nitrogen $\left(60,120\right.$ and $\left.180 \mathrm{~kg} \mathrm{ha}^{-1}\right)$, phosphorous (70, 100 and $130 \mathrm{~kg} \mathrm{ha}^{-1}$ ) and beneficial microbes (with and without BM). A control treatment with no N, P and BM was also kept for comparison. Application of beneficial microbes significantly increased pods plant, seed pod, seed filling duration, 1000 seed weight, biological yield and seed yield as compared to control plots. Nitrogen applied at the rate of $180 \mathrm{~kg} \mathrm{ha}^{-1}$ increased pods plant ${ }^{-1}$, seed pod, seed filling duration, seed weight, biological yield and seed yield. Maximum pods plant ${ }^{-1}$, seed pod, early seed filling, heavier seed weight, biological yield, seed yield, and harvest index were observed in plots treated with $130 \mathrm{~kg}^{-} \mathrm{ha}^{-1}$ phosphorous. As comparison, the combine treated plots have more pods plant ${ }^{-1}$, seeds pod $^{-1}$, seed filling duration, heaviest seeds, biological yield, seed yield and harvest index as compared to control plots. It is concluded that application of beneficial microbes with $\mathrm{N}$ and $\mathrm{P}$ at the rate of $180 \mathrm{~kg} \mathrm{ha}^{-1}$ and $130 \mathrm{~kg} \mathrm{ha}^{-1}$, respectively, increased yield and its attributes for canola.
\end{abstract}

Keywords: nutrients, micro-organisms, production, Brassica napus.

\begin{abstract}
Resumo
Uma pesquisa foi realizada para avaliar o impacto de vários níveis de nitrogênio e fósforo, juntamente com micróbios benéficos, para aumentar a produtividade da canola. A pesquisa foi realizada no inverno de 2016-17 no Agronomy Research Farm, Universidade de Agricultura do Peshawar. O experimento foi conduzido por planejamento fatorial aleatorizado em blocos. $O$ estudo focou-se em três fatores, incluindo o teor de nitrogênio, N, (60, 120 e 180 kg.ha-1), o teor de fósforo, P, (70, 100 e $130 \mathrm{~kg} \mathrm{ha}^{-1}$ ) e a presença de micróbios benéficos (com BM e sem BM). Para fins de comparação, um tratamento controle sem N, P e BM também foi incluído no estudo. A aplicação de micróbios benéficos aumentou significativamente as vagens das plantas e de sementes, a duração do enchimento das sementes, o peso de 1000 sementes, o rendimento biológico e o rendimento de sementes em comparação com os resultados do controle. $O$ nitrogênio aplicado na taxa de $180 \mathrm{~kg} \mathrm{ha}^{-1}$ aumentou as vagens por planta, vagem, duração do enchimento, peso da semente, rendimento biológico e rendimento de sementes. Vagens máximas por planta, vagem, enchimento precoce de sementes, peso maior de semente, rendimento biológico, rendimento de sementes e índice de colheita foram observados em parcelas tratadas com $130 \mathrm{~kg}_{\text {.ha }}{ }^{-1}$ de fósforo. Em comparação aos blocos cultivados de controle, os blocos cultivados tratados combinados têm mais vagens por planta e sementes por vagem, maior duração do enchimento das sementes, maior número de sementes mais pesadas e maior rendimento biológico, rendimento de sementes e índice de colheita. Conclui-se que a aplicação de micróbios benéficos junto com N e P nas doses de $180 \mathrm{~kg} \mathrm{ha}^{-1}$ e $130 \mathrm{~kg} \mathrm{ha}^{-1}$, respectivamente, aumentou a produtividade e atributos de produtividade para a canola.
\end{abstract}

Palavras-chave: nutrientes, microrganismos, produção, Brassica napus.

\section{Introduction}

World wide food demands are increasing day by day, especially in developing countries, where crop lands and resources hardly contribute to an efficient crop production (Bargaz et al., 2018). Majority of Farmers only rely on

chemical fertilizer which not only deteriorates quality of soil but also increases cost of production. Using of beneficial microbes with fertilizers are integrated approaches to reduce dependency on chemical fertilizers with the

*e-mail: asimmuh@aup.edu.pk

Received: 22 August, 2019 - Accepted: 5 November, 2020 
advantage of low cost of production (Imran, 2019). In Pakistan rapeseed is a vital palatable oilseed crop though its average yield is very low i.e. less than $812 \mathrm{~kg} \mathrm{ha}^{-1}$ compared to Canada where average yield is $3200 \mathrm{~kg} \mathrm{ha}^{-1}$ and Australia (2000 kg ha-1). The yield is low in Pakistan because it is cultivated on marginal land with poor fertility status, the lack of proper crop nutrition and unavailability of beneficial microbes. Nitrogen is an important element in the chemical arrangement of chlorophyll, the molecule accountable for changing light into chemical energy that drives photosynthesis (Havlin, 2005). Moreover, most of the applied $\mathrm{N}$ is lost in the environment through volatilization or leaching down. Therefore for efficient utilization of applied $\mathrm{N}$ fertilizer, proper strategy should be followed in timely and balance application of nitrogenous fertilizer to crop. The soils of Pakistan are mostly calcareous in nature. $P$ availability in calcareous soil is a major problem because in calcareous soil P is adsorbed in to insoluble form and become unavailable to the plants (Barber, 1995). The application of nitrogen and phosphorous are essential for getting maximum crop production. But their inadequate and imbalance reduced the yield. Beneficial microbes not only enhance nutrient uptake, but also regulate plant growth, improved photosynthetic efficiency nutrient use efficiency, tolerance to stress condition i.e (heat tolerance, resistance to insects and resistance to plant diseases) (Calabi-Floody et al., 2018).

Beneficial microbes composed of different mixed strains of bacteria, naturally-occurring such as photosynthetic bacteria (e.g., Rhodopseudomonas palustris, Rhodobacter sphaeroides), lactobacilli (e.g., Lactobacillus plantarum L. casei, and Streptococcus lactis), yeasts (e.g., Saccharomyces spp.), and Actinomycetes (Streptomyces spp.) (Javaid, 2010). Providing photosynthetic bacteria to the field enhances other beneficial microbes. For example, vesicular-arbuscular mycorrhiza level were increased in the rhizosphere due to the availability of nitrogenous compounds by photosynthetic bacteria (Kleiber et al., 2014). Vesiculararbuscular mycorrhiza increase the availability and solubility of phosphorous in the soils for crops. As lactic acid acts to sterilise soils and suppress harmful microorganisms, as well as increasing the decomposition of organic matter (Cóndor et al., 2007). Lactic acid bacteria also enhance the breakdown of organic matter. Similarly yeasts synthesis, anti-microbial compounds that also promote growth of crop from sugars and amino acids secreted by photosynthetic bacteria. Yeasts, can promote active cell and root division. Actinomycetes, produce anti-microbial substances can suppress harmful fungi and bacteria. These microorganisms are possible tools for sustainable agriculture and in combination of these different microbial strains could be a good multifunctional biofertilizer for sustainable agriculture (Kumar and Gopal, 2015) and when applied to seed, plant surfaces or soil colonize the plant and encourage its growth by increasing the nutrient availability (Thakur et al., 2018). It was confirmed that application of beneficial microbes to the soil can improve soil fertility and soil quality (Maheswari and Elakkiya,
2014). Moreover, beneficial Microbes have an effect on the availability of nutrients (Górski and Kleiber, 2010).

The application of beneficial microbes along with NPK enhanced yields significantly (Joshi et al., 2019). Beneficial microbes appeared to promote early growth and yield in different crops (Backer et al., 2018). The application of beneficial microbes enhance the fertilizer use efficiency (Bargaz et al., 2018). It was reported that beneficial microbes have the beneficial effects on crop yield and yield components of cereal crops (rice, wheat) and in legume i.e. mung-bean and vegetables (Seran and Shahardeen, 2013). Therefore, the present research was carried out to evaluate the effect of different nitrogen, phosphorus levels with beneficial microbes on yield and yield components of canola. To sustain fertility status of the soil, it is important to provide nutrients and beneficial soil organisms for intensive sustainable agriculture (Pankhurst and Lynch, 1995).

Application of adequate and balanced major nutrients are must to securing higher productivity in a sustainable manner, therefore nutrient management with relevant beneficial micro-organisms are highly required.

\section{Materials and Methods}

\subsection{Experimental design and treatments}

The experiment was carried out in randomized complete block design having three replications. The experiment consisted of three nitrogen levels $(60,120$, $180 \mathrm{Kg} \mathrm{ha}^{-1}$ ), three phosphorous levels (70, 100 and $130 \mathrm{Kg} \mathrm{ha}^{-1}$ ) and application of beneficial microbes (with and without). Urea and single super phosphate were used for nitrogen and phosphorous as sources, respectively. The cultivar of Brassica 'Zahoor' was sown at the seed rate of $10 \mathrm{~kg} \mathrm{ha}^{-1}$ in the $3^{\text {rd }}$ week of October 2016 . The size of the plot was $3.5 \mathrm{~m} \times 2.8 \mathrm{~m}$, having 8 rows, $40 \mathrm{~cm}$ apart. The field was irrigated four times when required. The canola field was weeded three times after every 30 days before flowering.

\subsection{Soil and environmental characteristics}

The field experiment was located in Peshawar $34^{\circ} 01^{\prime} 06^{\prime \prime} \mathrm{N}, 71^{\circ} 27^{\prime} 59^{\prime \prime} \mathrm{E}$, at an altitude of $350 \mathrm{~m}$ above sea level. Peshawar is located about $1600 \mathrm{~km}$ north of the Indian Ocean and has semiarid climate. The soil sample of the experimental site have $\mathrm{pH}(7.5)$, EC $(605 \mu \mathrm{S} / \mathrm{cm})$, soil texture (Silt loam), organic matter (0.80\%), 0.065\% $\mathrm{N}, 13 \mathrm{mg} \mathrm{kg}^{-1}$ available $\mathrm{P}, 230 \mathrm{mg} \mathrm{kg}^{-1}$ available $\mathrm{K}$ and there were no said beneficial microbes according to the soil microbiology laboratory, Department of Soil and Environmental Sciences. Data on different meteorological parameters (Maximum and minimum temperature, relative humidity, rainfall and solar radiation) of experimental site was measured during growing season of the crop (2016-17). Mean monthly maximum and minimum temperature $\left({ }^{\circ} \mathrm{C}\right)$, solar radiation $\left(\mathrm{MJ} \mathrm{m}^{-2} \mathrm{day}^{-1}\right)$, relative humidity (\%) and rainfall $(\mathrm{mm})$ of the growing season of canola crop $(2,016-2,017)$ (Figure 1). 


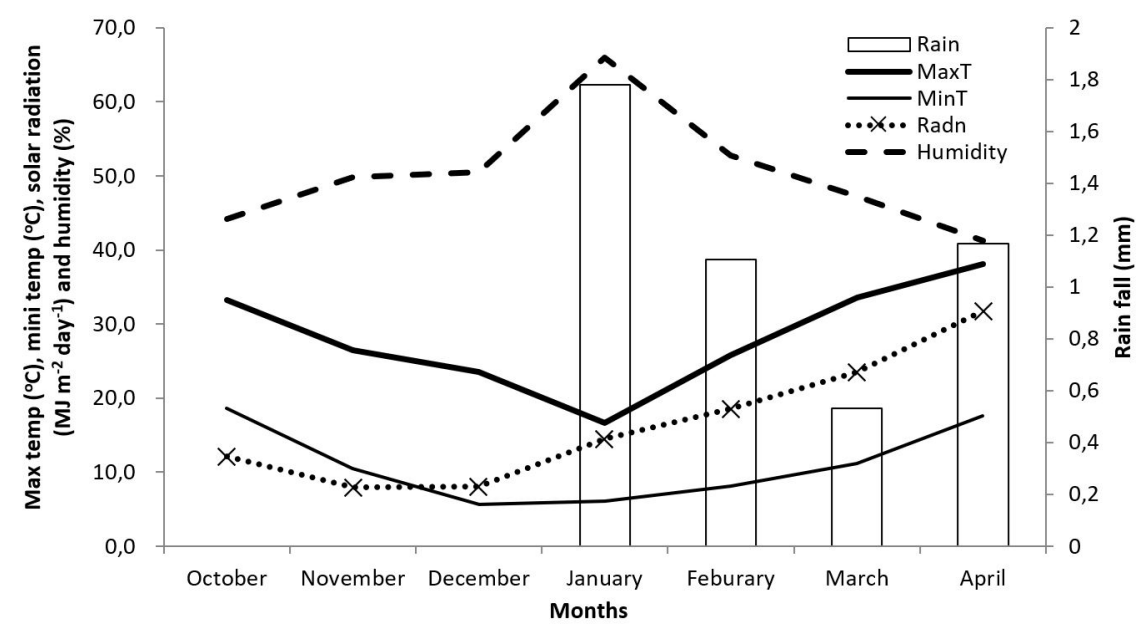

Figure 1. Mean monthly maximum \& minimum temperature $\left({ }^{\circ} \mathrm{C}\right)$, solar radiation (), relative humidity $(\%)$ and rainfall $(\mathrm{mm})$ of the growing season of canola crop (2,016-2,017).

\subsection{Beneficial microbes application}

Beneficial microbes stock solution was obtained from National Agriculture Research Center, Islamabad, Pakistan. Beneficial microbe's solution consisted of predominant population of photosynthetic bacteria i.e. Rhodo pseudomonas plastris and Rhodobacter sphacrodes; lactobacilli (Lactobacillus plantarum L. casei and Streptococcus lactis), yeasts (Saccharomyces cerevisiae) and actinomycetes viz. Strptomyces griseoviridis. Before its application to the field a solution was made containing one part of beneficial microbes with one part of $1 \%$ sugar solution plus 20 parts water by volume kept in dark for several hours. The activated beneficial microbes solution was diluted to $1: 1000$ by adding sterilized water. And the applied to the plots at the rate of at $2 \mathrm{~L} \mathrm{~m}^{-2}$

\subsection{Procedure for recording data}

Data concerning the days to emergence was recorded by counting the number of days from sowing to $50 \%$ of the seedlings' emergence in each subplot. Days to seed filling were measured by counting number of days when seed become fully filled at the growth stage " 80 ". About thirty five (35) to fourty five (45) days after the flower opens seed filling is complete. when seed filling complete, it contains nearly 40 to $45 \%$ moisture (Thurling, 1974). Pods plant $^{-1}$ and seeds pod ${ }^{-1}$ were measured by counting pods and seed pod $^{-1}$ in five randomly selected plants in each subplot and averaged it respectively (Manaf et al., 2017). Thousand grains weight ( $\mathrm{g}$ ) was measured by taking seed lot of thousands grains from each subplot and weighed with digital balance repetited three times. Data on biological yield $\left(\mathrm{kg} \mathrm{ha}^{-1}\right)$ was recorded by harvesting three central rows in each sub plot, sun dried, weighed and after that data was converted to $\mathrm{kg} \mathrm{ha}^{-1}$ using following Formula 1 (Ahmad et al., 2005):

Biological yield $\left(\frac{\mathrm{kg}}{\mathrm{ha}}\right): \frac{\text { Biological yield }(\mathrm{kg} / \mathrm{ha})}{\mathrm{r}-\mathrm{r} \text { distance } \mathrm{x} \text { no.of rows } \mathrm{x} \text { row length }} \times 10,000 \mathrm{~m}$
Seed yield $\left(\mathrm{Kg} \mathrm{ha}^{-1}\right)$ was measured by threshing, cleaning and weighing the seeds from harvested rows and data was converted in $\mathrm{kg} \mathrm{ha}^{-1}$ using Formula 2 (Younis et al., 2020):

$$
\text { Grain yield }\left(\frac{\mathrm{kg}}{\mathrm{ha}}\right): \frac{\text { Grain yield }(\mathrm{kg} / \mathrm{ha})}{\mathrm{r}-\mathrm{r} \text { distance } \mathrm{x} \text { no.of rows } \mathrm{x} \text { row length }} \times 10,000 \mathrm{~m}
$$

\subsection{Data analysis}

The data collected were analysed using the procedure appropriate for randomized complete block (RCB) design. Means was compared using Least Significant Difference (LSD) test at the $5 \%$ level of probability when $\mathrm{F}$ values were significant (Jan et al., 2009).

\section{Results and Discussion}

\subsection{Days to emergence}

Analysis of variance exhibited that days to emergence of canola was not significantly affected by nitrogen, phosphorus, beneficial microbes (Table 1). The planned mean comparison of control vs rest and all the interactions were also found non-significant for days to emergence (Table 1). However maximum days to emergence (11) was recorded in control plots as compared with beneficial microbes treated plots (10).

\subsection{Days to seed fill duration}

Days to seed fill duration of canola were significantly affected by different nitrogen levels, beneficial microbes and mean comparison of control vs rest (Table 1 ). The effect of phosphorus levels and all the interactions were found non-significant. The planned mean comparison of control with fertilized plots exhibited that more days (122) were taken to seed fill duration by the fertilized treatment as compared to control (110). Regarding nitrogen levels, seed filling stage was delayed with increasing nitrogen level from 60 to $180 \mathrm{~kg} \mathrm{ha}^{-1}$ and more days (126) to seed filling 
stage were taken with application of $180 \mathrm{~kg} \mathrm{~N} \mathrm{ha}^{-1}$, followed by $120 \mathrm{~kg} \mathrm{~N}^{-1}$ (120). Nitrogen influenced vegetative growth and crop canopy, which may delay phenology of maize. Earlier seed filling stage (119) was observed with addition of $60 \mathrm{~kg} \mathrm{~N} \mathrm{ha}^{-1}$. Application of beneficial microbes took more days (120) to seed filling stage as compared with no BM application (123). Phosphorus at the rate of $122 \mathrm{~kg} \mathrm{ha}^{-1}$ increased days to seed filling (122) as compared to higher doses ( $\left.130 \mathrm{~kg} \mathrm{ha}^{-1}\right)$ which decreased days to seed filling (121).

\subsection{Thousand seed weight ( $g$ )}

Different nitrogen and phosphorus levels, beneficial microbes and mean comparison of control vs rest significantly affected thousand seeds weight of canola (Table 2). All the interactions except BM x N were found non-significant. The mean comparison of control vs rest revealed that heavier grains $(4.5 \mathrm{~g})$ were produced by fertilized treatment as compared to control (3.8 g). Mean values of nitrogen revealed that application of $180 \mathrm{~kg} \mathrm{~N} \mathrm{ha}^{-1}$ produced heavier seeds ( $4.7 \mathrm{~g}$ ) which was statistically equal to thousand seeds weight $(4.5 \mathrm{~g})$ noticed

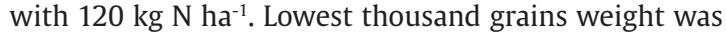
recorded with $60 \mathrm{~kg} \mathrm{~N}^{-1}(4.2 \mathrm{~g})$. The phosphorous applied at the rate of $130 \mathrm{~kg} \mathrm{ha}^{-1}$ produced heavier grains (4.7 g), which was statistically at par with $100 \mathrm{~kg} \mathrm{P} \mathrm{ha}^{-1}$ (4.5 g). Addition of $70 \mathrm{~kg} \mathrm{P} \mathrm{ha-1} \mathrm{produced} \mathrm{lighter} \mathrm{seeds}$ (4.2 g). Application of BM produced heavier seeds ( $4.8 \mathrm{~g}$ ) in comparison with no treatment of plots with BM $(4.2 \mathrm{~g})$.

Table 1. Days to emergence, pods plant ${ }^{-1}$, seeds $\operatorname{pod}^{-1}$ and days to seed filling duration as affected beneficial microbes with nitrogen and phosphorus levels.

\begin{tabular}{|c|c|c|c|c|}
\hline Treatments & Emergence & Pods plant $^{-1}$ & Seeds pod ${ }^{-1}$ & Seed Filling \\
\hline \multicolumn{5}{|l|}{ Beneficial microbes } \\
\hline Without & 10 & $224 b$ & $20.2 \mathrm{~b}$ & $120 \mathrm{~b}$ \\
\hline With & 10 & $241 \mathrm{a}$ & $23.3 \mathrm{a}$ & $123 \mathrm{a}$ \\
\hline \multicolumn{5}{|l|}{ Nitrogen (kg ha-1) } \\
\hline 60 & 10 & $218 c$ & $20.2 \mathrm{~b}$ & $119 \mathrm{c}$ \\
\hline 120 & 10 & $235 \mathrm{~b}$ & $22.5 \mathrm{~b}$ & $120 \mathrm{~b}$ \\
\hline 180 & 10 & $246 \mathrm{a}$ & $22.7 \mathrm{a}$ & $126 \mathrm{a}$ \\
\hline \multicolumn{5}{|l|}{ Phosphorus (kg ha-1) } \\
\hline 70 & 10 & $222 c$ & $19.9 \mathrm{c}$ & 122 \\
\hline 100 & 10 & $230 \mathrm{~b}$ & $21.6 \mathrm{~b}$ & 122 \\
\hline 130 & 10 & $240 \mathrm{a}$ & $23.8 \mathrm{a}$ & 121 \\
\hline Control & 11 & $182 \mathrm{~b}$ & $17.7 \mathrm{~b}$ & $110 \mathrm{~b}$ \\
\hline Rest & 10 & $233 a$ & $21.8 \mathrm{a}$ & $122 \mathrm{a}$ \\
\hline
\end{tabular}

Table 2. Thousand grain weight $(\mathrm{g})$, biological yield $\left(\mathrm{kg} \mathrm{ha}^{-1}\right)$, seed yield $\left(\mathrm{kg} \mathrm{ha}^{-1}\right)$ and Harvest index $(\%)$ of canola as affected beneficial microbes with nitrogen and phosphorus levels.

\begin{tabular}{|c|c|c|c|c|}
\hline Treatments & 1000 seed wt & Biological yield & Seed yield & Harvest index \\
\hline \multicolumn{5}{|l|}{ Beneficial microbes } \\
\hline Without & $4.2 \mathrm{~b}$ & $9583 \mathrm{~b}$ & $1394 \mathrm{~b}$ & $14.6 \mathrm{~b}$ \\
\hline With & $4.8 \mathrm{a}$ & $10357 \mathrm{a}$ & 1484 a & $14.4 \mathrm{a}$ \\
\hline \multicolumn{5}{|l|}{ Nitrogen (kg ha-1) } \\
\hline 60 & $4.2 \mathrm{~b}$ & 9479 c & $1380 \mathrm{~b}$ & $14.6 \mathrm{ab}$ \\
\hline 120 & $4.5 \mathrm{a}$ & $9950 \mathrm{~b}$ & $1487 \mathrm{a}$ & $15 \mathrm{a}$ \\
\hline 180 & $4.7 \mathrm{a}$ & $10481 \mathrm{a}$ & $1450 \mathrm{a}$ & $13.9 \mathrm{~b}$ \\
\hline \multicolumn{5}{|c|}{ Phosphorus (kg ha-1) } \\
\hline 70 & $4.2 \mathrm{~b}$ & $9581 \mathrm{~b}$ & 1311 c & $13.8 \mathrm{~b}$ \\
\hline 100 & $4.5 \mathrm{a}$ & $10002 \mathrm{a}$ & $1437 \mathrm{~b}$ & $14.4 \mathrm{~b}$ \\
\hline 130 & $4.7 \mathrm{a}$ & 10327 a & 1569 a & $15.3 \mathrm{a}$ \\
\hline Control & $3.8 \mathrm{~b}$ & $8009 \mathrm{~b}$ & $1002 \mathrm{~b}$ & $12.5 \mathrm{~b}$ \\
\hline Rest & $4.5 \mathrm{a}$ & 9970 a & 1439 a & $14.5 \mathrm{a}$ \\
\hline
\end{tabular}

Means of the same category followed by different letters are significantly different at $5 \%$ level of probability using LSD test. 
The interaction between BM and nitrogen indicated that increasing nitrogen level from 60 to $180 \mathrm{~kg} \mathrm{ha}^{-1}$ increased thousand seeds weight with BM application. While plots with no BM application, seeds weight were decreased with increasing nitrogen (180 kg ha-1) (Figure 2c). Application of beneficial microbes in sesame significantly increased 1000 seed weight and seed yield (Yasari et al., 2008). These beneficial microbes produced some useful substances i.e. amino acids, polysaccharides, nucleic acids, bioactive substances, and sugars, all of which promote plant growth and development. The metabolites which are produced by these microbes are readily absorbed by the crops (Higa, 2000). The crops required high NPK during the initial growth, therefore the crops that gain high supply of nitrogen would increase the vegetative growth and yield (Rorie et al., 2011).

\subsection{Number of pods plant $^{-1}$}

Different nitrogen and phosphorus levels, beneficial microbes and mean comparison of control vs rest significantly affected number of pods plant ${ }^{-1}$ of canola (Table 1). All the possible interactions were found nonsignificant. Mean comparison of control vs rest indicated that more pods were produced in fertilized plots (233) as compared to unfertilized plots (182). Mean values of nitrogen revealed that increasing nitrogen level consistently increased pods plant ${ }^{-1}$ and more pods (246) were produced with addition of $180 \mathrm{~kg} \mathrm{~N} \mathrm{ha}^{-1}$, followed by $120 \mathrm{~kg} \mathrm{~N} \mathrm{ha}^{-1}$ (235). Addition of $60 \mathrm{~kg} \mathrm{~N} \mathrm{ha}^{-1}$ produced lower pods (218). Likewise, increasing phosphorus application consistently increased pods plant ${ }^{-1}$ and application of $130 \mathrm{~kg} \mathrm{P} \mathrm{ha}^{-1}$ produced higher pods (246), followed by $100 \mathrm{~kg} \mathrm{P} \mathrm{ha}^{-1}$ (230). Pods was lowest (222) with addition of $70 \mathrm{~kg} \mathrm{P} \mathrm{ha}^{-1}$. Regarding beneficial microbes, BM application increased pods (241) as compared to no BM application (224).

\subsection{Number of seeds pods ${ }^{-1}$}

Number of seeds pod $^{-1}$ of canola was significantly affected by different nitrogen and phosphorus levels, beneficial microbes and mean comparison of control vs rest significantly affected number of pods plant ${ }^{-1}$ of canola (Tables 1 and 3). All the interactions between $\mathrm{N} \mathrm{x}$ $\mathrm{P}$ and $\mathrm{BM} x \mathrm{P}$ were found non-significant (Tables 4). Mean comparison of control vs rest indicated that more number of seeds pod $^{-1}$ were produced in fertilized plots (21.8) as compared to unfertilized plots (17.7). Mean values for nitrogen revealed that increasing nitrogen level from 60 to $180 \mathrm{~kg} \mathrm{ha}^{-1}$, seeds pod ${ }^{-1}$ were increased from 20.2 to 22.7. Which was statistically similar with number of seeds (22.5) produced with $120 \mathrm{~kg} \mathrm{~N} \mathrm{ha}^{-1}$. Addition of $60 \mathrm{~kg} \mathrm{~N} \mathrm{ha}^{-1}$ produced lower number of pods (20.2). The increase in seeds pod ${ }^{-1}$ might be due to the fact that nitrogen enhanced the growth of the crop and produced more dry matter that resulted in more seeds pod $^{-1}$. Likewise, increasing
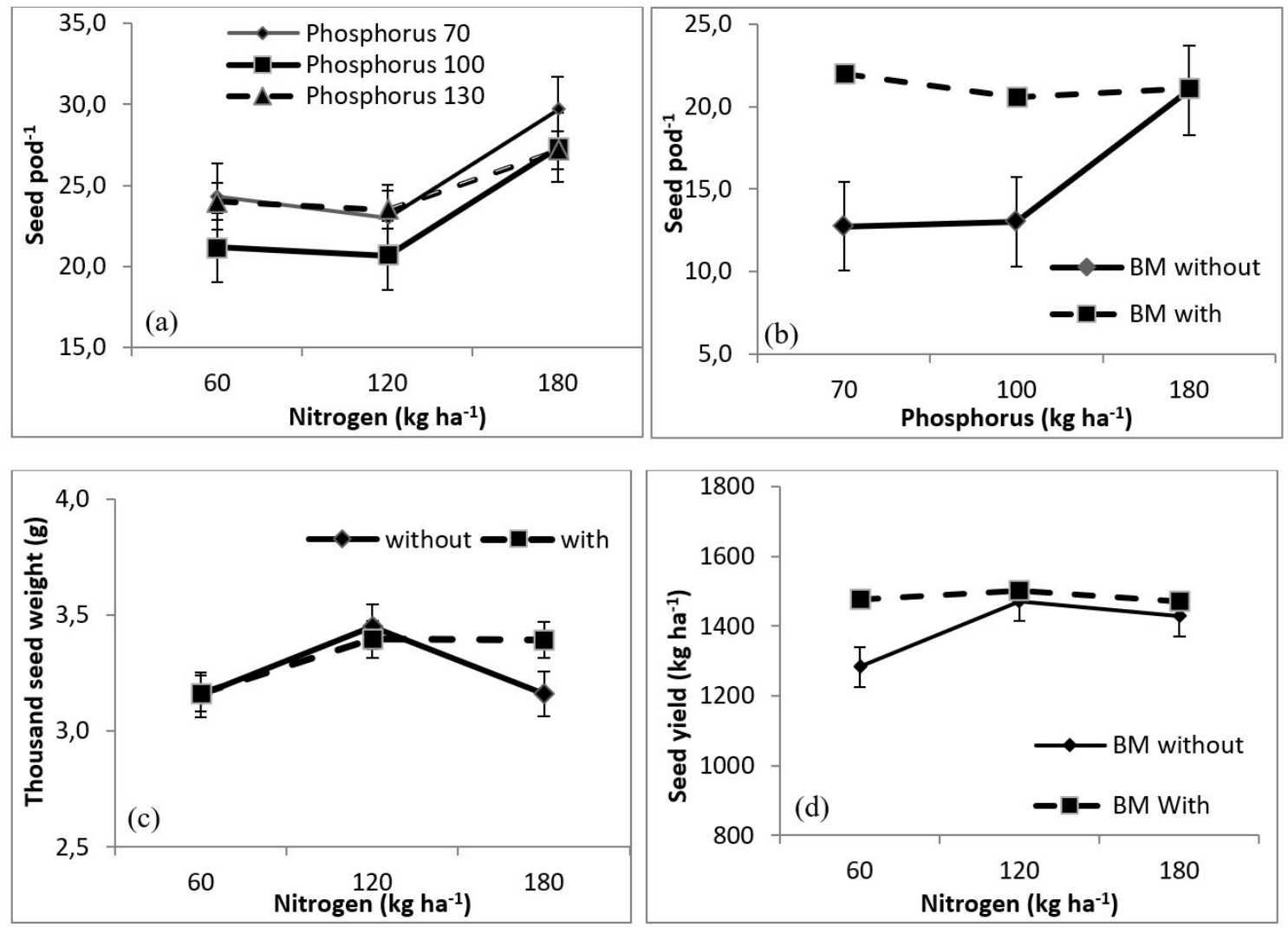

Figure 2. Interaction between nitrogen $x$ phosphorus for seeds $\operatorname{pod}^{-1}(a)$, phosphorous $x$ beneficial microbes for seeds pod ${ }^{-1}(b)$, nitrogen $\mathrm{x}$ beneficial microbes for grains weight $(\mathrm{c})$, and nitrogen $\mathrm{x}$ beneficial microbes for seed yield $\left(\mathrm{kg} \mathrm{ha}^{-1}\right)$ of canola $(\mathrm{d})$. 
Table 3. LSD at (0.05) for days to emergence, pods plant ${ }^{-1}$, seeds pod $^{-1}$, days to seed filling duration, thousand seed weight ( $\mathrm{g}$ ), biological yield $\left(\mathrm{kg} \mathrm{ha}^{-1}\right)$, seed yield $\left(\mathrm{kg} \mathrm{ha}^{-1}\right)$ and harvest index $(\%)$ of canola.

\begin{tabular}{|c|c|c|c|}
\hline Parameters & Nitrogen $(\mathrm{N})$ & Phosphorus (P) & Beneficial microbes (BM) \\
\hline Days to emergence & Ns & Ns & Ns \\
\hline Pods plant $^{-1}$ & 8 & 8 & 6 \\
\hline Seeds pod ${ }^{-1}$ & 1.7 & 1.7 & 1.4 \\
\hline Seed filling duration & 5 & NS & 4 \\
\hline Thousand grain weight & 0.3 & 0.3 & 0.2 \\
\hline Biological yield & 459 & 459 & 375 \\
\hline Seed yield & 41 & 41 & 33 \\
\hline Harvest index & 0.8 & 0.8 & NS \\
\hline
\end{tabular}

Table 4. Analysis of variance for days to emergence, pods plant ${ }^{-1}$, seeds pod $^{-1}$ and days to seed filling duration of canola as affected by beneficial microbes with nitrogen and phosphorus levels.

\begin{tabular}{|c|c|c|c|c|c|}
\hline SOV & Df & Emergence & Pods plant $^{-1}$ & Seeds pod ${ }^{-1}$ & Seed fill duration \\
\hline Replication & 2 & 15.368 & 133.737 & 2.333 & 1.333 \\
\hline Nitrogen $(\mathrm{N})$ & 2 & $2.074 \mathrm{Ns}$ & $3514.889^{* *}$ & $35.167^{* *}$ & $226.741^{* *}$ \\
\hline Phosphorus (P) & 2 & $0.963 \mathrm{Ns}$ & $2641.556^{* *}$ & $66.500^{* *}$ & $0.352 \mathrm{Ns}$ \\
\hline Beneficial microbes (BM) & 1 & $2.667 \mathrm{Ns}$ & $3986.963^{* *}$ & $130.667^{* *}$ & $192.667^{* *}$ \\
\hline Control vs Rest & 1 & $1.887 \mathrm{Ns}$ & $7328.035^{* *}$ & $48.035^{* *}$ & $377.080^{* *}$ \\
\hline $\mathrm{N} \times \mathrm{P}$ & 4 & $1.519 \mathrm{Ns}$ & 158.194 Ns & $21.250^{* *}$ & $5.491 \mathrm{Ns}$ \\
\hline $\mathrm{N} \times \mathrm{BM}$ & 2 & $3.556 \mathrm{Ns}$ & $234.963 \mathrm{Ns}$ & $9.056 \mathrm{Ns}$ & $96.222 \mathrm{Ns}$ \\
\hline $\mathrm{P} \times \mathrm{BM}$ & 2 & $1.556 \mathrm{Ns}$ & $58.963 \mathrm{Ns}$ & $26.722^{* *}$ & $6.056 \mathrm{Ns}$ \\
\hline $\mathrm{N} \times \mathrm{P} \times \mathrm{S}$ & 4 & $2.111 \mathrm{Ns}$ & $138.546 \mathrm{Ns}$ & $2.194 \mathrm{Ns}$ & $75.361 \mathrm{Ns}$ \\
\hline Error & 36 & 2.035 & 125.700 & 6.333 & 45.833 \\
\hline Total & 56 & & & & \\
\hline CV (\%) & & 14.42 & 4.87 & 11.67 & 5.60 \\
\hline
\end{tabular}

SOV=Source of variation, DF=Degree of freedom, ${ }^{*},{ }^{* *},{ }^{* * *}$ : significant at $\mathrm{P} \leq 0.05,0.01$, and 0.001 , respectively.

phosphorus application consistently increased number of seeds pod ${ }^{-1}$. Application of $130 \mathrm{~kg} \mathrm{P} \mathrm{ha}^{-1}$ produced higher number of seeds pod ${ }^{-1}$ (23.8), followed by $100 \mathrm{~kg} \mathrm{P} \mathrm{ha}^{-1}$ (21.6). Number of seeds pod ${ }^{-1}$ was lowest (19.9) with addition of $70 \mathrm{~kg} \mathrm{P} \mathrm{ha}^{-1}$. Regarding beneficial microbes, BM application produced more number of seeds $\operatorname{pod}^{-1}$ (23.3) as compared to no BM application (20.2). The interaction $\mathrm{N} x$ P indicated that number of seeds pod ${ }^{-1}$ increased with the increasing $\mathrm{N}$ from 60 to $180 \mathrm{~kg} \mathrm{ha}^{-1}$ and phosphorous from 70 and $100 \mathrm{~kg} \mathrm{P} \mathrm{ha}^{-1}$, however slight decrease was observed with increasing $\mathrm{N}$ at $130 \mathrm{~kg} \mathrm{P} \mathrm{ha}^{-1}$ (Figure 2a). The interaction between $\mathrm{BM}$ and $\mathrm{P}$ revealed that increasing P level from 70 to $130 \mathrm{~kg} \mathrm{ha}^{-1}$ increased number of seeds pod $^{-1}$ without BM application however the increase was more prominent with BM application plots (Figure 2b).

\subsection{Biological yield $\left(\mathrm{kg} \mathrm{ha}^{-1}\right)$}

Statistical analysis of the data showed that biological yield of canola was significantly affected by nitrogen and phosphorus levels, beneficial microbes and mean comparison of control vs. rest. While all the possible interactions were found non-significant (Table 2). Mean values of the data indicated that control plots produced less biological yield ( $8009 \mathrm{~kg} \mathrm{ha}^{-1}$ ) as compared to rest of the fertilized plots $\left(9970 \mathrm{~kg} \mathrm{ha}^{-1}\right)$. Nitrogen applied at $180 \mathrm{~kg} \mathrm{ha}^{-1}$ produced more biological yield $\left(10480 \mathrm{~kg} \mathrm{ha}^{-1}\right)$, which was followed by $120 \mathrm{~kg} \mathrm{~N} \mathrm{ha}^{-1}\left(9950 \mathrm{~kg} \mathrm{ha}^{-1}\right)$. Lower biological yield ( $\left.9479 \mathrm{~kg} \mathrm{ha}^{-1}\right)$ was obtained with nitrogen application at the rate of $60 \mathrm{~kg} \mathrm{ha}^{-1}$. Among different phosphorous levels, $130 \mathrm{~kg} \mathrm{P} \mathrm{ha}^{-1}$ produced higher biological yield (10327 kg ha-1), which was statistically similar with yield (10002 kg ha-1) obtained from $100 \mathrm{~kg} \mathrm{P} \mathrm{ha}^{-1}$. The application of phosphorous at the rate of $70 \mathrm{~kg} \mathrm{ha}^{-1}$ produced lowest biological yield (9581 kg ha-1).

Beneficial microbes produced more biological yield (10357 $\mathrm{kg} \mathrm{ha}^{-1}$ ) as compared to no beneficial microbes applied plots (9583 $\mathrm{kg} \mathrm{ha}^{-1}$ ).

\subsection{Seed yield $\left(\mathrm{kg} \mathrm{ha}^{-1}\right)$}

Statistical analysis of the data showed that seed yield of canola was significantly affected by nitrogen, phosphorus levels, beneficial microbes and control vs. rest (Table 2). All the possible interactions except BM x N were found non-significant. Mean comparison of control vs. rest 
indicated that the fertilized plots produced more seed yield (1439 kg ha-1) as compared to control plots (1002 kg ha-1). Mean values for nitrogen ( $\left.120 \mathrm{~kg} \mathrm{~N} \mathrm{ha}^{-1}\right)$ observed maximum seed yield $\left(1487 \mathrm{~kg} \mathrm{ha}^{-1}\right)$, which was statistically at par with $180 \mathrm{~kg} \mathrm{~N} \mathrm{ha}^{-1}\left(1450 \mathrm{~kg} \mathrm{ha}^{-1}\right)$. The nitrogen application at the rate of $60 \mathrm{~kg} \mathrm{ha}^{-1}$ produced lower seed yield $\left(1380 \mathrm{~kg} \mathrm{ha}^{-1}\right)$. Application of phosphorous at the rate of $130 \mathrm{~kg} \mathrm{ha}^{-1}$ produced higher seed yield (1569 $\mathrm{kg} \mathrm{ha}^{-1}$ ), followed by $100 \mathrm{~kg} \mathrm{P} \mathrm{ha}^{-1}\left(1437 \mathrm{~kg} \mathrm{ha}^{-1}\right)$. Lowest seed yield was recorded (1311 kg ha-1 $)$ at $70 \mathrm{~kg} \mathrm{P} \mathrm{ha}^{-1}$. Regarding BM, addition of BM increased seed yield ( $1484 \mathrm{~kg} \mathrm{ha}^{-1}$ ) as compared to without BM applied (1394 $\left.\mathrm{kg} \mathrm{ha}^{-1}\right)$. The interaction between BM and $\mathrm{N}$ revealed that seed yield increased with increasing $\mathrm{N}$ from 60 to $120 \mathrm{~kg} \mathrm{ha}^{-1}$. However the increase was more prominent in without BM application. Further, increasing $\mathrm{N}$ beyond $120 \mathrm{~kg} \mathrm{ha}^{-1}$ decrease seed yield (Figure $2 \mathrm{~d}$ ).

\subsection{Harvest index (\%)}

Harvest index of canola was significantly affected by nitrogen and phosphorus levels, as well as control vs rest (Table 2). The effect of BM and all the possible interactions were found non-significant (Table 5). Mean comparison of control vs rest showed that higher harvest index (14.5\%) was observed in fertilized plots as compared to control plots (12.5\%). The nitrogen applied at the rate of $120 \mathrm{~kg} \mathrm{~N} \mathrm{ha}^{-1}$ had higher harvest index (15.0\%), followed by $60 \mathrm{~kg} \mathrm{~N} \mathrm{ha}^{-1}$ (14.6\%). The nitrogen application at the rate of $180 \mathrm{~kg} \mathrm{ha}^{-1}$ had lowest harvest index (13.9\%). In case of phosphorus levels, application of $130 \mathrm{~kg} \mathrm{P} \mathrm{ha}^{-1}$ had higher harvest index (15.3\%), followed by $100 \mathrm{~kg} \mathrm{P} \mathrm{ha}^{-1}$ (14.4\%).

\section{Discussion}

Days to emergence was non-significantly affected by nitrogen, phosphorus, beneficial microbes and it interactions. It might be due that the young plants take nutrients from the store food in the endosperm of seed and there is no response of fertilizer at early germination stage. It was reported that seedling emergence is mostly related to the reserved food present in seed (Le Gouis et al., 1999). Seeds used their own endosperm for germination and did not utilize food from any other sources (Hadi et al., 2012).

The increase in days to seed fill duration with application of nitrogen might be due to the fact that increasing nitrogen increased the vegetative growth of the plants therefore it delayed phenology of the crop (Banziger et al., 1999). Similar results were previously reported that increasing nitrogen application delayed the maturity of the crop (Kutcher et al., 2005). Delayed phenology is associated with the increase in leaf area duration, vegetative growth and light use efficiency with increased nitrogen levels (Rehman et al. 2010).

Pods plant ${ }^{-1}$ was increased through using nitrogen at the rate of $200 \mathrm{~kg} \mathrm{ha}^{-1}$ and $150 \mathrm{~kg} \mathrm{ha}^{-1}$ with beneficial microbes as compared to lowest pods plant ${ }^{-1}$ was observed in control plots (Asl, 2017). Regarding beneficial microbes, BM application increased pods (241) as compared to no BM application (224). Application of beneficial microorganisms increased pods plant ${ }^{-1}$, pods cluster ${ }^{-1}$, seeds pod $^{-1}$, hundred seed weight ( $\mathrm{g}$ ), pod yield plant ${ }^{-1}$ and pod yield hectare ${ }^{-1}$ in common bean (Ramana et al., 2011). Highest cabbage seed yields and yield attributes were recorded with the application of $150 \mathrm{~kg}$ Phosphorous ha- ${ }^{-1}$ combined with BM (Olle and Williams, 2015). Beneficial microbes significantly increased all the seed yield and their attributes i.e., seed plant $^{-1}$, seed dry weigh plant ${ }^{-1}$ and seed pod ${ }^{-1}$ (Iriti et al., 2019). Beneficial microbe's application increased the pod production in Chili (Khaing and Kyu, 2016). A much greater effect of BM on the yield of chilli and bell pepper (Kodippili and Nimalan, 2018). According to Moraditochaee et al., (2011), nitrogen application could fulfill the requirement for $\mathrm{N}$ and increase number of fruits and total yield. Chickpea pods plant ${ }^{-1}$ were significantly increased with application

Table 5. Analysis of variance for thousand grain weight $(\mathrm{g})$, biological yield $\left(\mathrm{kg} \mathrm{ha}^{-1}\right)$, seed yield $\left(\mathrm{kg} \mathrm{ha}^{-1}\right)$ and harvest index $(\%)$ of canola as affected by beneficial microbes with nitrogen and phosphorus levels.

\begin{tabular}{|c|c|c|c|c|c|}
\hline SOV & Df & $\begin{array}{c}1000 \text { grains } \\
\text { weight }\end{array}$ & Biological yield & Seed yield & Harvest index \\
\hline Replication & 2 & 0.286 & 1266744 & 6647 & 6.094 \\
\hline Nitrogen $(\mathrm{N})$ & 2 & $1.260^{* *}$ & $4515306^{* *}$ & $52843^{* *}$ & $5.293^{* *}$ \\
\hline Phosphorus (P) & 2 & $1.031^{* *}$ & $2516587^{* *}$ & $299834^{* *}$ & $9.954^{* *}$ \\
\hline Beneficial microbes (BM) & 1 & $5.019^{* *}$ & $8098366^{* *}$ & $108631^{* *}$ & $0.527 \mathrm{Ns}$ \\
\hline Control vs Rest & 1 & $1.460^{* *}$ & $10929788^{* *}$ & $542478^{* *}$ & $10.770^{* *}$ \\
\hline $\mathrm{N} \times \mathrm{P}$ & 4 & $0.026 \mathrm{Ns}$ & $135796 \mathrm{Ns}$ & 2047 Ns & $0.129 \mathrm{Ns}$ \\
\hline $\mathrm{N} \times \mathrm{BM}$ & 2 & $0.832^{* *}$ & 20146 Ns & $36981^{* *}$ & $3.183 \mathrm{Ns}$ \\
\hline $\mathrm{P} \times \mathrm{BM}$ & 2 & $0.081 \mathrm{Ns}$ & $429324 \mathrm{Ns}$ & $975 \mathrm{Ns}$ & $1.211 \mathrm{Ns}$ \\
\hline $\mathrm{N} \times \mathrm{P} \times \mathrm{S}$ & 4 & $0.015 \mathrm{Ns}$ & $382790 \mathrm{Ns}$ & $2631 \mathrm{Ns}$ & $1.026 \mathrm{Ns}$ \\
\hline Error & 36 & 0.159 & 460463 & 3660 & 1.300 \\
\hline Total & 56 & & & & \\
\hline CV (\%) & & 8.98 & 6.88 & 4.27 & \\
\hline
\end{tabular}

SOV=Source of variation, DF=Degree of freedom, ${ }^{*},{ }^{* *},{ }^{* * *}$ : significant at $\mathrm{P} \leq 0.05,0.01$, and 0.001 , respectively. 
of beneficial microbes as compared with control plots (Rabieyan et al., 2011). Seeds pod and pods plant increasead significantly with the application of beneficial microbes with inorganic fertilizers (Singh Kothyari et al., 2017).

The increase in seeds pod $^{-1}$ might be due to the fact that nitrogen enhanced the growth of the crop and produced more dry matter that resulted in more seeds $\operatorname{pod}^{-1}$. The plants took more nitrogen and enhanced the rate of photosynthesis which resulted in more vigorous growth (Tusar-Patra et al., 2006). Integrated application of beneficial microbes with chemical nitrogen fertilizer increased yield and yield components of canola compared to control (treated plants with beneficial microbes without using chemical nitrogen fertilizer (Keivanrad and Zandi, 2012).

Number of seeds pod ${ }^{-1}$ was lowest (19.9) with addition of $70 \mathrm{~kg} \mathrm{P} \mathrm{ha-1}$. Application of chemical and beneficial microbes increased physiological and metabolic activities in sesame accumulating more dried materials in plants and seeds pod $^{-1}$ (Yasari et al., 2008). Regarding beneficial microbes, BM application produced more number of seeds $\operatorname{pod}^{-1}$ (23.3) as compared to no BM application (20.2). It was concluded that use of beneficial microbes significantly increased yield and yield attributes of canola (Jashankar and Wahab, 2005).

The increase in days to seed fill duration with application of nitrogen might be due to the fact that increasing nitrogen increased the vegetative growth of the plants therefore it delayed phenology of the crop (Banziger et al., 1999). Similar results were previously reported that increasing nitrogen application delayed the maturity of the crop (Kutcher et al., 2005). Delayed phenology is associated with the increase in leaf area duration, vegetative growth and light use efficiency with increased N levels (Rehman et al. 2010). Effective microbes had positive impact on growth and play a vital role in crop phenology (Vaid et al., 2017).

Lowest thousand grains weight was recorded with $60 \mathrm{~kg} \mathrm{~N} \mathrm{ha}^{-1}$ (4.2 g). Increasing nitrogen levels increased grain weight for which the probable reason is that higher availability of nitrogen increases the nutrients uptake and enhanced the dry matter accumulation in grains which resulted in heavier grain (Hamidi et al., 2007). The increase in yield is strongly correlated with increased in yield components such as siliques plant ${ }^{-1}$, grains silique ${ }^{-1}$, and grains weight (Malidarreh, 2010; Ogrodowczyk and Wawrzyniak, 2004). Application of beneficial microbes in sesame significantly increased 1000 seed weight and seed yield (Yasari et al., 2008). These beneficial microbes produced some useful substances i.e. amino acids, polysaccharides, nucleic acids, bioactive substances, and sugars, all of which promote plant growth and development. The metabolites which are produced by these microbes are readily absorbed by the crops (Higa, 2000). The crops required high NPK during the initial growth, therefore the crops that gain high supply of nitrogen would increase the vegetative growth and yield (Rorie et al., 2011).

The increase in biological yield with increasing nitrogen levels might be due to vigorous plant growth with addition of nitrogen. Moreover, nitrogen is a key nutrient and is constituent of plant tissues and play vital role in photosynthesis, thus increasing crop growth and dry matter production. It was observed that lower fertilizers rate had little effect on plant growth and biomass as compared to higher rates (Assainar et al., 2018). Similarly, application of nitrogen with beneficial microbes increased synthesis of assimilates and more dry matter were produced with higher level of nitrogen (Asl, 2017). Likewise, nitrogen is also known for increasing vegetative growth hence produced taller plants with greater canopy which leads to increased biological yield (Banziger et al., 1999). The increase in biological yield might be because of nitrogen enhanced the growth of the crop and produced more dry matter that resulted in increasing net biological yield. Increasing nitrogen levels increased biomass for which the probable reason is that higher availability of nitrogen increased the nutrients uptake and enhanced the dry matter accumulation in seeds (Hamidi et al., 2007). The increase in biological yield caused by the nitrogen levels might be due to increase in production of biomass and seed yield (Diepenbrock, 2000; Ahmadi and Bahrani, 2009). Application of phosphorous increased biological yield and dry matter production which might be due to its role in plant growth and developments. Phosphorous plays important role in early root development, which leads to more nutrient uptake and increased plant growth. These results are in agreement with the findings of several researchers who revealed that Phosphorous application increased the vegetative growth and biomass production effectively (Dinesh et al., 2010; Meena et al. 2018; Minorsky, 2008). Moreover, it was found that application of Phosphorous increased the growth, dry matter accumulation, yield and quality of plant (Mishra and Jain, 2013). Application of mineral Phosphorous with beneficial microbe significantly enhanced the availability of photo assimilates which in turn increased biological yield. Beneficial bacteria were used in combination they perform better in comparison to their individual use, and significantly increase the mean grain and straw yield by $34 \%$ and $52.4 \%$ over none inoculated control (Vaid et al., 2017).

The increase in biological yield with addition of BM might be due to the ability of BM which increased nutrients availability through mineralization which leads to increased crop growth. BM increased nutrients availability which increased plant growth and thus more dry matter was accumulated in plant's tissues. Beneficial microbes improved crop growth and has significant effect on crop yield (Ghetiya et al., 2018).

The probable reason for increasing seed yield with application of nitrogen might be that nitrogen play an important role in plant growth and development. It helps in increasing photosynthetic rate and in results more dry matter is produced. Moreover seed yield is associated with yield components such as pods plant ${ }^{-1}$, seeds pod ${ }^{-1}$ and grain weight. Increasing nitrogen rate increased siliques plant $^{-1}$ therefore resulted in more siliques $\mathrm{m}^{-2}$ (Ali et al., 2002). The increase in seeds pod $^{-1}$ might be due to the fact that nitrogen enhanced the growth of the crop and produced more dry matter that resulted in more seeds pod $^{-1}$. Increasing nitrogen levels increased seeds weight for which the probable reason is that higher availability of nitrogen increases the nutrients uptake and enhanced the dry matter accumulation in grains which resulted in heavier 
grain (Hamidi et al., 2007). The crop yield increased due to the strongly correlated with increased in yield components such as siliques plant ${ }^{-1}$, grains silique ${ }^{-1}$, and grains weight (Malidarreh, 2010; Ogrodowczyk; Wawrzyniak, 2004). The probable reason for increasing seed yield with application of phosphorus might be that phosphorous played important role in root development during early growth stages and provided better crop stand which lead to vigorous crop growth and yield. Similarly increase in seed yield and yield components with addition of phosphorous as compared to no phosphorous application (Meena et al., 2018; Minorsky, 2008). Moreover, application of phosphorous increased the growth, dry matter accumulation (Manhas et al., 2010), yield and quality of plant (Ramesh et al., 2011; Mishra and Jain, 2013). Regarding BM, addition of BM increased seed yield ( $1484 \mathrm{~kg} \mathrm{ha}^{-1}$ ) as compared to without BM applied (1394 kg ha-1). The probable reason for increase in yield and yield components of canola with the addition of BM might be that BM improved soil fertility and increase nutrients availability which lead to higher nutrients uptake and increased crop production. Application of $\mathrm{BM}$ increased soil fertility and enhanced nutrient use efficiency which lead to higher crop yield (Javaid, 2006; Khaliq et al., 2006). Similarly beneficial microorganism increase crop yield by enhancing nutrient availability in the soil (Priyadi et al., 2005). BM improve crop health and yield by increasing photosynthesis, producing bioactive substances such as hormones and enzymes (Higa, 2000; Hussain et al., 2002). The application of BM increased yield and yield components of maize (Dehghani et al., 2013). This might be due to high photosynthetic activity with higher nitrogen availability and the plants consumed nitrogen efficiently due to its higher availability and produced more dry matter resulting in higher number of siliques plant $^{-1}$. The nitrogen rate affected the crop physiology, in terms of a slight delay in the first day of flowering and time until maturity (Karamzadeh et al., 2010).

Harvest index was not affected by the microbial inoculants but was decreased with all fertilizer treatments as compared to control (Assainar et al., 2018). Grain yield and harvest index increased with beneficial microbes application and NPK fertilizers (Javaid and Bajwa, 2011). The beneficial microbes increased the grain yield and harvest index of the crop (Xu, 2001). The beneficial microbes application either in combination with organic matter or mineral NPK significantly enhanced cotton yield as compared to the treatments, where these soil amendments were used without BM application (Khaliq et al., 2006).

\section{Conclusions}

Nitrogen applied at the rate of $180 \mathrm{Kg} \mathrm{ha}^{-1}$ increased pods plant ${ }^{-1}$, seeds pod $^{-1}$, seed filling duration, seed weight, and biological yield. While phosphorous applied at the rate of $130 \mathrm{Kg} \mathrm{ha}^{-1}$ increased pods palnt ${ }^{-1}$, seeds pod ${ }^{-1}$, seed wt, biological yield, seed yield and harvest index. The crops treated with beneficial microbes had maximum pods plant ${ }^{-1}$, seeds pod $^{-1}$, seed filing duration, seed weight, biological yield and seed yield.

\section{Acknowledgements}

The authors are thankful to Directorate of Farm, The University of Agriculture Peshawar for providing field, seeds and cultivation of canola.

\section{References}

AHMAD, A., KHAN, I., ANJUM, N., DIVA, I., ABDIN, M. and IQBAL, M., 2005. Effect of timing of sulfur fertilizer application on growth and yield of rapeseed. Journal of Plant Nutrition, vol. 28, no. 6, pp. 1049-1059. http://dx.doi.org/10.1081/PLN-200058905.

AHMADI, M. and BAHRANI, M.J., 2009. Yield and yield components of rapeseed as influenced by water stress at different growth stages and nitrogen levels. American-Eurasian Journal of Agriculture and Environamental Science, vol. 5, no. 6, pp. 755-761.

ALI, N., JAVIDFAR, F. and ATTARY, A.A., 2002. Genetic variability, correlation and path analysis of yield and its components in winter rapeseed (Brassica napus L.). Pakistan Journal of Botany, vol. 34, no. 2, pp. 145-150.

ASL, A.N., 2017. Effects of nitrogen and phosphate biofertilizers on morphological and agronomic characteristics of sesame (Sesamum indicum L.). Open Journal of Ecology, vol. 7, no. 2, pp. 101-111. http://dx.doi.org/10.4236/oje.2017.72008.

ASSAINAR, S.K., ABBOTT, L.K., MICKAN, B.S., WHITELEY, A.S., SIDDIQUE, K.H.M. and SOLAIMAN, Z.M., 2018. Response of wheat to a multiple species microbial inoculant compared to fertilizer application. Frontiers of Plant Science, vol. 9, pp. 1601. http://dx.doi.org/10.3389/fpls.2018.01601. PMid:30483282.

BACKER, R., ROKEM, J.S., ILANGUMARAN, G., LAMONT, J., PRASLICKOVA, D., RICCI, E., SUBRAMANIAN, S. and SMITH, D.L., 2018. Plant growth-promoting rhizobacteria: context, mechanisms of action, and roadmap to commercialization of biostimulants for sustainable agriculture. Frontiers of Plant Science, vol. 9, pp. 1473. http://dx.doi.org/10.3389/ fpls.2018.01473. PMid:30405652.

BÄNZIGER, M., EDMEADES, G.O. and LAFITTE, H.R., 1999. Selection for drought tolerance increases maize yields across a range of nitrogen levels. Crop Science, vol. 39, no. 4, pp. 1035-1040. http:// dx.doi.org/10.2135/cropsci1999.0011183X003900040012x.

BARBER, S.A., 1995. Soil nutrient bioavailability. New York: John Wiley \& Sons.

BARGAZ, A., LYAMLOULI, K., CHTOUKI, M., ZEROUAL, Y. and DHIBA, D., 2018. Soil microbial resources for improving fertilizers efficiency in an integrated plant nutrient management system. Frontiers in Microbiology, vol. 9, pp. 1606. http://dx.doi.org/10.3389/ fmicb.2018.01606. PMid:30108553.

CALABI-FLOODY, M., MEDINA, J., RUMPEL, C., CONDRON, L.M., HERNANDEZ, M., DUMONT, M. and DE LA LUZ MORA, M., 2018. Smart fertilizers as a strategy for sustainable agriculture. Advances in Agronomy, vol. 147, pp. 119-157. http://dx.doi. org/10.1016/bs.agron.2017.10.003.

CÓNDOR, A., GONZÁLEZ, P. and LOKARE, C., 2007. Effective Microorganisms: myth or reality? Revista Peruana de Biología, vol. 14, no. 2, pp. 315-319.

DEHGHANI, I., KORDLAGHARI, K.P. and MOHAMADINIA, G., 2013. Effect of effective microorganisms activate (EMa) on growth, yield and yield components of corn in Firozabad region. Annals of Biological Research, vol. 4, no. 4, pp. 126-129.

DIEPENBROCK, W., 2000. Yield analysis of winter oilseed rape (Brassica napus L.), a review. Field Crops Research, vol. 67, no. 1, pp. 35-49. http://dx.doi.org/10.1016/S0378-4290(00)00082-4. 
DINESH, R., SRINIVASAN, V., HAMZA, S. and MANJUSHA, A., 2010. Short term incorporation of organic manures and fertilizers influences biochemicals and microbial characteristics of soils under an annual crop turmeric. Bioresource Technology, vol. 101, no. 12, pp. 4697-4702. http://dx.doi.org/10.1016/j. biortech.2010.01.108. PMid:20163953.

GHETIYA, K.P., BHALU, V.B., MATHUKIA, R.K., HADAVANI, J.K. and KAMANI, M.D., 2018. Effect of Phosphate and Potash Solubilizing Bacteria on Growth and Yield of Popcorn (Zea Mays L. Var. Everta). International Journal of Pure and Applied Bioscience, vol. 6, no. 5, pp. 167-174. http://dx.doi.org/10.18782/2320-7051.6918.

GÓRSKI, R. and KLEIBER, T., 2010. The effect of Effective Microorganisms (EM) on nutrient contents in substrate and development and yielding of rose (Rosa $\times$ hybrida) and gerbera (Gerbera jamesonii). Ecological Chemistery and Engineerings, vol. 17, no. 4, pp. 505-513.

HADI, M.R.H.S., DARZI, M.T. and GHANDEHARI, Z., 2012. Effects of irrigation treatment and Azospirillum inoculation on yield and yield component of black cumin (Nigella sativa L.). Journal of Medicinal Plants Research, vol. 6, no. 30, pp. 4553-4561.

HAMIDI, A., ASGHARZADEH, A., CHOUKAN, R., SHOAR, M.D., GHALAV, A. and MALAKOUTI, M.J., 2007. Study on plant growth promoting rhizobacteria (PGPR) biofertilizers application in maize (Zea mays L.) cultivation by adequate input. Environmental Sciences, vol. 4, no. 4, pp. 1-19.

HAVLIN, J.L., 2005. Soil fertility $\mathcal{E}$ fertilizers: an introduction to nutrient management. 7th ed. Upper Saddle River: Pearson Prentice Hall, 503 p.

HIGA, T., 2000. What is EM technology? EM World Journal, vol. 1, pp. 1-6.

HUSSAIN, T., ANJUM, A.D. and TAHIR, J., 2002. Technology of beneficial microorganisms. Natural Farm Environment, vol. 3, pp. 1-14.

IMRAN, 2019. Plant-microbe interactions in agronomic crops. In: M. HASANUZZAMAN, ed. Agronomic crops. Singapore: Springer.

IRITI, M., SCARAFONI, A., PIERCE, S., CASTORINA, G. and VITALINI, S., 2019. Soil application of effective microorganisms (EM) maintains leaf photosynthetic efficiency, increases seed yield and quality traits of bean (Phaseolus vulgaris L.) plants grown on different substrates. International Journal of Molecular Sciences, vol. 20, no. 9, pp. 2327. http://dx.doi.org/10.3390/ ijms20092327. PMid:31083418.

JAN, M.T., SHAH, P., HOOLINTON, P.A., KHAN, M.J. and SOHAIL, Q., 2009. Agriculture research: design and analysis. Peshawar: Department of Agronomy, NWFP Agricultural University.

JASHANKAR, S. and WAHAB, K., 2005. Effect of integrated nutrient management on the growth, yield components and yield of sesame. Sesame and Safflower Newsletter, vol. 20, pp. 602-608.

JAVAID, A., 2010. Beneficial microorganisms for sustainable agriculture. In: E. LICHTFOUSE, ed. Genetic engineering, biofertilisation, soil quality and organic farming. Dordrecht: Springer, pp. 347-369. Sustainable Agriculture Reviews, no. 4. http://dx.doi.org/10.1007/978-90-481-8741-6_12.

JAVAID, A. and BAJWA, R., 2011. Field evaluation of effective microorganisms (EM) application for growth, nodulation, and nutrition of mung bean. Turkish Journal of Agriculture and Forestry, vol. 35, pp. 443-452.

JAVAID, A., 2006. Foliar application of effective microorganisms as an alternative fertilizer for pea. Agronomy Sustainable Devlopment, vol.26, no.4, pp. 257-262. http://dx.doi.org/10.1051/ agro:2006024.

JOSHI, H., DUTTAND, S., CHOUDHARY, P. and MUNDRA, S.L., 2019. Role of Effective Microorganisms (EM) in Sustainable
Agriculture. International Journal of Current Microbiology and Applied Sciences, vol. 8, no. 3, pp. 172-181. http://dx.doi. org/10.20546/ijcmas.2019.803.024.

KARAMZADEH, I.A., MOBASSER, I.H.R., RAMEE, V. and MALIDARREH, A.G., 2010. Effects of nitrogen and seed rates on yield and oil content of canola. American-Eurasian Journal of Agricultural $\&$ Environmental Sciences, vol. 8, no. 6, pp. 715-721.

KEIVANRAD, S. and ZANDI, P., 2012. Effect of nitrogen levels on growth, yield and oil quality of Indian mustard grown under different plant densities. Thai Journal of Agricultural Science, vol. 45, pp. 105-113.

KHAING, M.M. and KYU, K., 2016. Effects of priming tests and fertilizer applications on germination, growth and yields of chilli (Capsicum annum L). Hinthada University Research Journal, vol. 7, no. 1, pp. 97-105.

KHALIQ A., ABBASI, M.K. and HUSSAIN, T., 2006. Effect of integrated use of organic and inorganic nutrient sources with effective microorganisms (EM) on seed cotton yield in Pakistan. Bioresource Technology, vol. 97, no. 8, pp. 967-972. http:// dx.doi.org/10.1016/j.biortech.2005.05.002. PMid:16023343.

KLEIBER, T., JUSTYNA, S., ROMUALD, G., KRZYSZTOF, S., MAREK, S., ANNA, R., AGATA, S., TOMASZ, K., JUSTYNA, S., ROMUALD, G., KRZYSZTOF, S., MAREK, S., ANNA, R. and AGATA, S., 2014. The studies on applying of effective microorganisms (EM) and CRF on nutrient contents in leaves and yielding of tomato. Acta Scientiarum Polonorum. Hortorum Cultus, vol. 13, no. 1, pp. 79-90.

KODIPPILI, K.P.A.N. and NIMALAN, J., 2018. Effect of homemade effective microorganisms on the growth and yield of chilli (Capsicum annuum) MI-2. Agrieast, vol. 12, no. 2, pp. 27-34. http://dx.doi.org/10.4038/agrieast.v12i2.57.

KUMAR, B.L. and GOPAL, D.S., 2015. Effective role of indigenous microorganisms for sustainable environment. 3 Biotech, vol. 5, no. 6, pp. 867-876.

KUTCHER, H.R., MALHI, S.S. and GILL, K.S., 2005. Topography and management of nitrogen and fungicide affects diseases and productivity of canola. Agronomy Journal, vol. 97, no. 2, pp. 533-541. http://dx.doi.org/10.2134/agronj2005.0533.

LE GOUIS, J., DELEBARRE, O., BEGHIN, D., HEUMEZ, E. and PLUCHARD, P., 1999. Nitrogen uptake and utilization efficiency of two-row and six-row winter barley cultivars grown at two $\mathrm{N}$ levels. European Journal of Agronomy, vol. 10, no. 2, pp. 73-79. http:// dx.doi.org/10.1016/S1161-0301(98)00055-0.

MAHESWARI, N.U. and ELAKKIYA, T., 2014. Effect of liquid biofertilizers on growth and yield of Vignamungo L. International Journal of Pharmaceutical Sciences Review and Research, vol. 29, no. 2, pp. 42-45.

MALIDARREH, A.G., 2010. Effects of nitrogen rates and splitting on oil content and seed yield of canola. American-Eurasian Journal of Agriculture and Environomental Sciences, vol. 8, no. 2, pp. 161-166.

MANAF, A., KASHIF, M., SIDDQUE, M.T., SATTAR, A. and SHER, A., 2017. Soil Applied Boron Improved Productivity and Oil Yield of Canola Cultivars. Pakistan Journal of Life and Social Sciences, vol. 15 , no. 2, pp. 90-95.

MANHAS, S.S., GILL, B.S. and SHARMA, S., 2010. Effect of different planting material, planting dates and harvesting dates on economy of turmeric crop. Journal of Agriculture Physics, vol. 10, pp. 50-52.

MEENA, R.S., DAS, A., YADAV, G.S. and RATTAN, L., 2018. Legumes for soil health and sustainable management. Singapor: Springer, 130 p. http://dx.doi.org/10.1007/978-981-13-0253-4.

MINORSKY, P.V., 2008. On the inside. Plant Physiology, vol. 146, no. 2, pp. 323-324. http://dx.doi.org/10.1104/pp.104.900246. 
MISHRA, S. and JAIN, A., 2013. Effect of integrated nutrient management on \& rographolide content of \& rographis paniculata. Nature and Science, vol. 11, no. 8, pp. 30-32.

MORADITOCHAEE, M., BOZORGI, H.R. and HALAJISANI, N., 2011. Effects of vermicompost application and nitrogen fertilizer rates on fruit yield and several attributes of eggplant (Solanum melongenalL.) in Iran. Journal of World Applied Science, vol. 15, no. 2, pp. 174-178.

OGRODOWCZYK, M. and WAWRZYNIAK, M., 2004. Adoption and path- coefficient analysis for assessment of relationship and interrelationship of yield and yield parameters of winter oilseed rape. Rosliny Oleiste, vol. 25, no. 2, pp. 479-491.

OLLE, M. and WILLIAMS, I., 2015. Effective microorganisms and their influence on vegetable production: a review. The Journal of Horticultural Science E Biotechnology, vol. 88, no. 4, pp. 380-386. http://dx.doi.org/10.1080/14620316.2013.11512979.

PANKHURST, C. and LYNCH, J., 1995. The role of soil microbiology in sustainable intensive agriculture. Advances in Plant Pathology, vol. 11, pp. 229-247. http://dx.doi.org/10.1016/ S0736-4539(06)80014-0.

PRIYADI, K., HADI, A., SIAGIAN, T.H., NISA, C., AZIZAH, A., RAIHANI, N. and INUBUSHI, K., 2005. Effect of soil type, applications of chicken manure and effective microorganisms on corn yield and microbial properties of acidic wetland soils in Indonesia. Soil Science and Plant Nutrition, vol. 51, no. 5, pp. 689-691. http:// dx.doi.org/10.1111/j.1747-0765.2005.tb00092.x.

RABIEYAN, Z., YARNIA, M., and KAZEMI-E-ARBAT, H., 2011. Effects of biofertilizers on yield and yield components of chickpea (Cicer arietinum L.) under different irrigation levels. Australian Journal of Basic and Applied Sciences, vol. 5, no. 12, pp. 3139-3145.

RAMANA, V., RAMAKRISHNA, M., PURUSHOTHAM, K.R. and BALAKRISHNA, K., 2011. Effect of biofertilizer on growth, yield and quality of french bean. Legume Research, vol. 33, no. 3, pp. 178-183.

RAMESH, G., SHIVANNA, M.B. and RAM, A.S., 2011. Interactive influence of organic manure and inorganic fertilizers on growth and yield of A. paniculata. International Journal of Plant Sciences, vol. 2, pp. 16-21.

REHMAN, S., SHAD, K.K., FIDA, M., ABDUR, R., AMIR, Z.K., AMANULLAH, AHMAD, R.S., MUHAMMAD, Z. and IFITIKHAR, H.K., 2010. Phenology, leaf area index and grain yield of rainfed wheat influenced by organic and inorganic fertilizer. Pakistan Journal of Botany, vol. 42, no. 5, pp. 3671-3685.

RORIE, R.L., PURCELL, L.C., MOZAFFARI, M., KARCHER, D.E., KING, C.A., MARSH, M.C. and LONGER, D.E., 2011. Association of
"Greenness" in corn with yield and leaf nitrogen concentration. Agronomy Journal, vol. 103, no. 2, pp. 529-535. http://dx.doi. org/10.2134/agronj2010.0296.

SERAN, T.H. and SHAHARDEEN, R.N.M., 2013. Marketable pod yield of vegetable cowpea (vigna unguiculata) as influenced by organic manures fermented with em solution. The Open Horticulture Jouurnal, vol. 6, pp. 19-23.

SINGH KOTHYARI, H., KUMAR YADAV, L., JAT, R. and CHAND GURJAR, P., 2017. Influence of biofertilizers on plant growth and seed yield of Pea (Pisum sativum L.). International Journal of Current Microbiology and Applied Sciences, vol. 6, no. 11, pp. 1810-1817. http://dx.doi.org/10.20546/ijcmas.2017.611.216.

THAKUR, S., THAKUR, R. and MEHTA, D.K., 2018. Effect of biofertilizers on horticultural and yield traits in french bean var. Contender under dry temperate conditions of Kinnaur district of Himachal Pradesh. Journal of Applied and Natural Science, vol. 10, no. 1, pp. 421-424. http://dx.doi.org/10.31018/ jans.v10i1.1641.

THURLING, N., 1974. Morphophysiological determinants of yield in rapeseed (Brassica campestris and Brassica napus L.). I. Growth and morphological characters. Australian Journal of Agricultural Research, vol. 25, no. 5, pp. 697-710. http://dx.doi. org/10.1071/AR9740697.

TUSAR-PATRA, P., MAITI, S. and MITRA, B., 2006. Variability correlation and path analysis of the yield attributing characters of mustard (Brassica spp.). Research on Crops, vol. 7, no. 1, pp. 191-193.

VAID, S.K., KUMAR, A., SHARMA, A., SRIVASTAVA, P.C. and SHUKLA, A.K., 2017. Role of some plant growth promotery bacteria on enhanced Fe uptake of wheat. Communications in Soil Science and Plant Analysis, vol. 48, no. 7, pp. 756-768.

XU, H.L., 2001. Effects of a microbial inoculant and organic fertilizers on the growth, photosynthesis and yield of sweet corn.Journal of Crop Production, vol. 3, no. 1, pp. 183-214. http://dx.doi. org/10.1300/J144v03n01_16.

YASARI, E., AZADGOLEH, A.M.E., PIRDASHTI, H. and MOZAFARI, S., 2008. Azotobacter and Azospirillum inoculants as biofertilizers in canola (Brassica napus L.) cultivation. Asian Journal of Plant Sciences, vol. 7, no. 5, pp. 490-494. http://dx.doi.org/10.3923/ ajps.2008.490.494.

YOUNIS, M., MUHAMMAD, A., ALAM, S. and JALAL, A., 2020. Sulphur doses and application times on yield and oil quality of canola grown in calcareous soil. Grasas y Aceites, vol. 71, no. 1, pp. 341. http://dx.doi.org/10.3989/gya.1176182. 